\title{
Performance of hepatitis rapid diagnostic tests in HIV-positive patients
}

\author{
Livia Melo Villar*,1 \\ ${ }^{1}$ Laboratory of Viral Hepatitis, Oswaldo Cruz Institute, Fiocruz, Rio de Janeiro, Brazil \\ *Author for correspondence: Tel.: 5521 25621918; Ivillar@ioc.fiocruz.br
}

\section{'6 HBV RDTs demonstrate a good performance among HIV-infected individuals and could be used to identify HBV cases, particularly in poor resource areas and emergency situations."}

First draft submitted: 22 April 2018; Accepted for publication: 2 May 2018; Published online:

7 August 2018

Keywords • hepatitis $B \bullet$ hepatitis $C \bullet$ HIV • rapid diagnostic

Over the world, hepatitis B and C viruses (HBV and HCV) are major causes of chronic liver disease. HBV and HCV prevalence varies according to age, risk behaviors, population studied, and presence of coinfection with other viruses such as HIV [1-4]. Among HIV-infected individuals, a high prevalence of HBV and HCV infection has been reported [3,4].

In 2015, only $20 \%$ of the 71 million people living with HCV infection globally (14 million) knew their diagnosis [5]. Among HIV infected subjects it is important to diagnose HBV and HCV infection as soon as possible since the presence of co-infection may worsen the prognosis of disease and modify the type of treatment [6]. Nowadays, rapid diagnostic tests (RDTs) are used for the diagnosis of HBV and HCV due to their utility in emergency situations and remote areas without infrastructure [7-9]. These assays have a good performance in the general population [10-13], but few studies have evaluated their performance in HIV-infected subjects.

Recently, Barbosa et al. [14]. found high sensitivity (>92\%) and specificity (>99\%) of RDTs Vikia HBsAg (Biomerieux, France) and Wama Immuno-Rapid HBsAg (Wama, Minas Gerais, Brazil) for both serum and whole blood specimens from HIV-infected subjects from Brazil. In addition, Franzeck et al. [7] found a sensitivity of 96\% and a specificity of $100 \%$ for the RDT, determine HBsAg, using serum and whole blood among HIV-1 patients on recent antiretroviral treatment in Tanzania. Davies et al. [15] found 100\% sensitivity and specificity for $\mathrm{HBsAg}$ detection in sera from 300 HIV-positive Malawian adults using the 'determine rapid hepatitis B' test.

On the other hand, Cruz et al. [9] found a high number of false negatives for the detection of HBsAg using RDTs Vikia HBsAg, Wama Immuno-Rapid HBsAg and Teste Rapido HBsAg (Doles, Brazil) in HIV-infected subjects in Brazil. Hoffmann et al. [16] found 75\% sensitivity and 100\% specificity of determine HBsAg in HIV-infected, antiretroviral naive adults attending primary or antenatal care in urban South Africa. These results could be due to the low number of HIV samples included or titers of HBsAg lower than the assay limit. Other important issues that could affect RDT performance should be evaluated, such as, the effect of HBV genotypes, HBV viral load and mutations in the HBV S gene.

RDTs for anti-HCV detection such as Wama Immuno-rapid anti-HCV ${ }^{\circledR}$ and Bioeasy HCV Rapid Test ${ }^{\circledR}$ have sensitivities greater than $80 \%$ in HIV-infected individuals, this is lower than that found among non-HIV-infected subjects [8,14,17]. Kosach et al. [18] found sensitivity of the OraQuick HCV test to be 65.2\% (95\% CI: 42.8-82.8) after $20 \mathrm{~min}$ and 73.9\% (95\% CI: 51.3-88.9) after $40 \mathrm{~min}$ of incubation among HIV/HCV-infected subjects. Using the Multisure HCV test and serum samples of the same subjects, the sensitivity was 96.2\% (95\% CI: 80.4-99.9).

The low sensitivity of HCV RDTs in HIV-infected individuals could be the result of the immune suppression caused by the virus which in turn decreases the production of anti-HCV antibodies [19,20]. In addition, samples presenting discordant results for anti-HCV antibody detection among RDTs and enzyme immunoassays (EIAs) also have high HIV viral load demonstrating a negative impact of HIV viral load on the efficiency of RDTs. However, RDTs had a great performance in identifying cases of active HCV viremia (anti-HCV antibodies/HCV

(a)

Future : Medicine 
RNA positive samples) in HIV-infected individuals [14], which could be helpful to identify those who should start on antiviral treatment.

Ribeiro et al. [14] also found that the performance of RDTs in the detection of HBsAg and anti-HCV antibodies is affected by antigen and antibody concentration among HIV-infected individuals since false-negative results in RDTs had lower mean ratio of optical density to cut off $(\mathrm{OD} / \mathrm{CO})$ values in EIA compared to true-positive samples. This situation could impact the usefulness of RDTs for HBV and HCV diagnosis in HIV-infected individuals who are in the early or convalescence period of infection. On the other hand, they did not observe low performance of RDTs for detection of HBV and HCV in relation to CD4 cell count and antiretroviral treatment. This could be very helpful since most of HIV-infected individuals are under treatment and present a high CD4 cell count.

In general, HBV RDTs demonstrate a good performance among HIV-infected individuals and could be used to identify HBV cases, particularly in poor resource areas and emergency situations. There is still controversy regarding the usefulness of HCV RDT in HIV infected individuals, Firdaus et al. [10] did not recommend these assays as the only diagnostic tool to be used in a high-risk group, such as HIV-positive individuals. However, these assays demonstrate good efficiency in identifying active HCV cases and in emergency situations or poor resource areas, could be the only method available. Public health authorities should evaluate the risk and benefits of using these methods among HIV-infected individuals.

\section{Acknowledgements}

This editorial is dedicated to health personnel of Viral Hepatitis Laboratory (Oswaldo Cruz Institute), especially to JR Barbosa who studied the performance of rapid tests of hepatitis B and C among HIV subjects.

\section{Financial \& competing interests disclosure}

This work was supported by Support Foundation to Research of the State of Rio de Janeiro (FAPERJ), the Brazilian National Council of Technological and Scientific Development (CNPq), and the Oswaldo Cruz Foundation (FIOCRUZ). The author has no other relevant affiliations or financial involvement with any organization or entity with a financial interest in or financial conflict with the subject matter or materials discussed in the manuscript apart from those disclosed.

No writing assistance was utilized in the production of this manuscript.

\section{References}

1 Villar LM, de Paula VS, de Almeida AJ, do Ó KM, Miguel JC, Lampe E. Knowledge and prevalence of viral hepatitis among beauticians. J. Med. Virol. 86(9), 1515-1521 (2014).

2 Villar LM, Amado LA, de Almeida AJ, de Paula VS, Lewis-Ximenez LL, Lampe E. Low prevalence of hepatitis B and C virus markers among children and adolescents. Biomed Res. Int. 2014, 324638 (2014).

3 Flores GL, de Almeida AJ, Miguel JC et al. A cross section study to determine the prevalence of antibodies against HIV Infection among Hepatitis B and C infected individuals. Int. J. Environ. Res. Public Health 13(3), pii:E314 (2016).

4 Ribeiro Barbosa J, Sousa Bezerra C, Carvalho-Costa FA et al. Cross-sectional study to determine the prevalence of hepatitis B and C virus infection in high-risk groups in the northeast region of Brazil. Int. J. Environ. Res. Public Health 14(7), pii:E793 (2017).

5 WHO. Hepatitis C (2018). www.who.int/mediacentre/factsheets/fs164/en/

6 Lacombe K, Rockstroh J. HIV and viral hepatitis co-infections: advances and challenges. Gut 61, 47-58 (2012).

7 Franzeck FC, Ngwale R, Msongole B et al. Viral hepatitis and rapid diagnostic test based screening for HBsAg in HIV-infected patients in rural Tanzania. PLoS ONE 8 (3), e58468 (2013).

8 Scalioni LP, Cruz HM, Paula VS et al. Performance of rapid hepatitis C virus antibody assays among high- and low-risk populations. J. Clin. Virol. 60(3), 200-205 (2014).

9 Cruz HM, Scalioni LP, Paula VS et al. Evaluating HBsAg rapid test performance for different biological samples from low- and high-infection rate settings \& populations. BMC Infect. Dis. 15, 548 (2015).

10 Firdaus R, Saha K, Sadhukhan PC. Rapid immunoassay alone is insufficient for the detection of hepatitis C virus infection among high-risk population. J. Viral Hepat. 20(4), 290-293 (2013).

11 Bottero J, Boyd A, Gozlan J et al. Performance of rapid tests for detection of HBsAg and anti-HBsAg in a large cohort, France. J. Hepatol. 58(3), 473-478 (2013).

12 Tang W, Chen W, Amini A et al. Diagnostic accuracy of tests to detect hepatitis C antibody: a meta-analysis and review of the literature. BMC Infect. Dis. 17(Suppl. 1), 695 (2017).

13 Amini A, Varsaneux O, Kelly $\mathrm{H}$ et al. Diagnostic accuracy of tests to detect hepatitis B surface antigen: a systematic review of the literature and meta-analysis. BMC Infect. Dis. 17(Suppl. 1), 698 (2017). 
14 Barbosa JR, Colares JKB, Flores GL et al. Performance of rapid diagnostic tests for detection of hepatitis B and C markers in HIV-infected patients. J. Virol. Methods 248, 244-249 (2017).

15 Davies J, van Oosterhout JJ, Nyirenda $\mathrm{M}$ et al. Reliability of rapid testing for hepatitis $\mathrm{B}$ in a region of high HIV endemicity. Trans. $R$. Soc. Trop. Med. Hyg. 104(2), 162-164 (2010).

16 Hoffmann CJ, Dayal D, Cheyip M et al. Prevalence and associations with hepatitis B and hepatitis C infection among HIV-infected adults in South Africa. Int. J. STD AIDS 23, e10-e13 (2012).

17 Rosa L, Dantas-Corrêa EB, Narciso-Schiavon JL, Schiavon LD. Diagnostic performance of two point-of-care tests for anti-HCV detection. Hepat Mon. 13, 9 (2013).

18 Kosack CS, Nick S. Evaluation of two rapid screening assays for detecting hepatitis C antibodies in resource-constrained settings. Trop. Med. Int. Health 21(5), 603-609 (2016).

19 Ross RS, Stambouli O, Gruner N et al. Detection of infections with hepatitis B virus, hepatitis C virus, and human immunodeficiency virus by analyses of dried blood spots-performance characteristics of the ARCHITECT system and two commercial assays for nucleic acid amplification. Virol. J. 10, 1 (2015).

20 Chonwattana W, Raengsakulrach B, Holtz TH et al. Hepatitis B vaccination uptake and correlates of serologic response among HIV-infected and uninfected men who have sex with men (MSM) in Bangkok, Thailand. Vaccine 34 (17), 2044-2050 (2016). 
